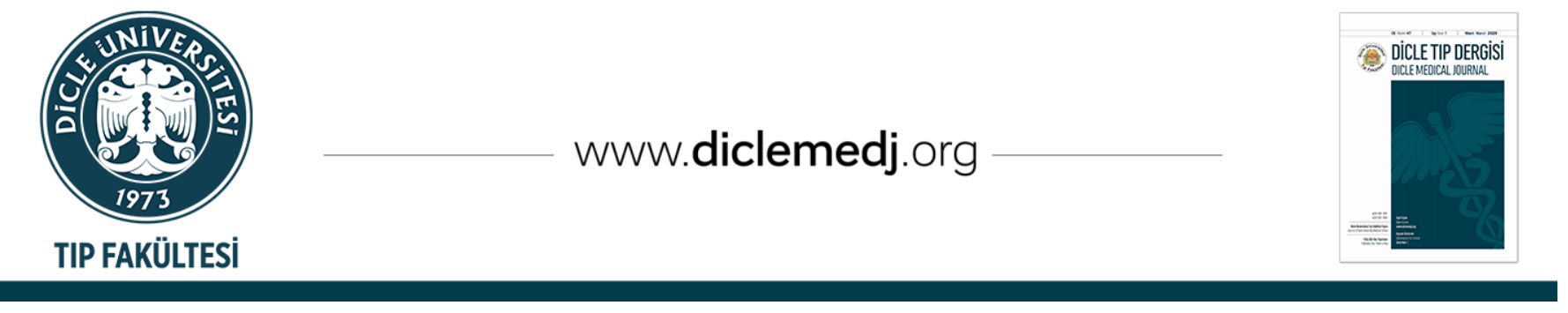

Özgün Araştırma / Original Article

\title{
Amniyosentez Uygulanan 217 Olgunun Analizi
}

\author{
Erdal Şeker iD ${ }^{1}$, Evindar Elçi iD ${ }^{2}$, Aydın Öçal iD ${ }^{3}$, Ahmet Yalınkaya iD 4 \\ 1 Ankara Üniversitesi Tıp Fakültesi, Kadın Hastalıkları ve Doğum ABD, Perinatatoli Bilim Dali, Ankara, Türkiye \\ 2 Kadın Hastalıkları ve Doğum Kliniği, Siirt Devlet Hastanesi, Siirt, Türkiye
}

3 SBÜ Zeynep Kamil EAH Perinataloji Bilim Dalı İstanbul, Türkiye

4 Dicle üniversitesi Tıp Fakültesi Kadın hastalıkları ve Doğum Kliniği Diyarbakır, Türkiye

Geliş: 24.12.2019; Revizyon: 19.04.2020; Kabul Tarihi: 29.04.2020

Öz

Amaç: Kliniğimizde amniyosentez (AS) uygulanan 217 olgunun sonuçlarını retrospektif olarak değerlendirmektir.

Yöntemler: Çalışmamıza Eylül 2011 ile Temmuz 2013 tarihleri arasında kliniğimizde AS uygulanan 217 olgu dâhil edildi. Bilgilere hasta dosyaları incelenerek ulaşıldı. Gebeliklerin prognozu ve bebeklerin durumu, hastalar telefon ile aranarak ulaşıldı. AS yapılmadan önce ayrıntılı ultrason (US) incelemesi yapıldı. AS uygulanan gebelerin yaşı, gravida, parite, abortus, yaşayan çocuk sayısı, gebelik haftası, tarama testleri ve US'de saptanan anomaliler kaydedildi. AS endikasyonları ise tarama testi pozitifliği, ileri anne yaşı, maternal anksiyete, daha önceden kromozom anomalili bebek doğurma öyküsü, US'de fetal anomali düşündüren bulgular olarak belirlendi.

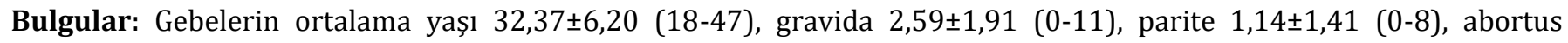
$0,51 \pm 0,91$ (0-5), yaşayan çocuk sayısı $1,09 \pm 1,03(0-8)$ ve gebelik haftası $17,58 \pm 1,80$ (13-27) olarak bulundu. AS endikasyonlarında ilk sırayı \%24,9 ile pozitif üçlü testin yer aldığı tespit edildi. AS uygulanan 18 (\%8) olguda karyotip anomalisi tespit edildi. Bu karyotip anomalilerinden 6'sı yaşamla bağdaşan anomalilerdir. Kromozomal anomali saptanan olgulardan 4'ü trizomi 21 (Down sendromu), 2'si trizomi 18 (Edward sendromu), 2'si monozomi x (Turner sendromu) ve sirasiyla birer olgu da trizomi 13 (Patau sendromu), trizomi 10, triploidi ve parsiyel tirizomi 10 (Pallister-Killian sendromu) idi. İzole ileri anne yaşı nedeni ile AS uygulanan 22 olgunun hiç birinde kromozomal anomali saptanmadı. Olguların hiç birinde işlemden sonra ilk üç haftada veya karyotip sonucu alındığı tarihe kadar abortus veya fetal kayıp izlenmedi. Hastaların 6'sı $(\% 2,76)$ preterm eylem nedeniyle erken doğum yaptı. Üç $(\% 1,30)$ olgumuzda intrauterin eksitus saptandı. İşlem sonrası hiçbir hastada maternal komplikasyon izlenmedi. 
Sonuç: Kromozomal anomaliler daha çok US'de fetal anomali saptanan ve birden çok nedene bağlı endikasyonlar ile AS uygulanan hasta grubunda saptanmıștır. Bu da prenatal tanı amacıyla yapılan anomali taramasının deneyimli ve konunun uzmanları tarafından yapılmasının daha yararlı olacağını göstermektedir. Yalnız ileri anne yaşının kromozomal anomali yakalama şansını fazla artırmadığını düşünüyoruz.

Anahtar kelimeler: Prenatal tanı, Amniyosentez, Karyotip, Kromozomal anomali

\title{
Analysis of 217 Cases Undergoing Amniocentesis
}

\begin{abstract}
Objective: The main purpose in prenatal diagnose is to have information about fetus health and to make a decision about the future of fetus as soon as possible. Prenatal diagnose is divided in two groups as invasive procedures and non-invasive scanning. Non invasive tests are still being used in screening and for a definitive diagnosis, diagnosis should be confirmed by invasive procedures. Therefore invasive diagnosis still keeps it's importance in prenetal diagnosis. Despite increasing rate of coryonic villus sampling(CVS), genetic amniocentesis (AS) is still a common performed as a prenetal diagnosis procedure. Although AS could be performed in each trimester of pregnancy, genetic AS commonly performed between 15-20th weeks of gestation.
\end{abstract}

Method This study was conducted between September 2011 and July 2013, and 217 patients included at the study. The patients who have had following indications underwent AS for a definitive diagnosis; pathological finding at family history and ultrasonography; high risk for double, triple and quadraple tests; advanced maternal age and maternal anxiety. High risk in triple test was the leading indication for AS followed by combine indications and pathological US finding.

Results The mean maternal age was $32.37 \pm 6.20$ and mean gestation age was $17.58 \pm 1.80$. AS was succesfully performed in each patient with one single try. The rate of chromosomal abnormality was found to be $8 \%$ in patients performed AS.No fetal loss occured due to AS.

Conclusion In case of performing AS with experts and high experienced doctors and if there is an optimum transport and culture conditions, it is an procedure with high reliability and accurancy. It's an important procedure for diagnosis with less complications seen due to the procedure.As a result, for definitive diagnosis of fetal chromosomal abnormalitiesi AS is still the most common used invasive method in prenatal diagnosis.

Keywords: prenatal diagnose,amniocentesis,chromosomal abnormality, indications, risks.

\section{GİRIŞ}

Her 10.000 doğumda down sendromu, trizomi 18 , trizomi 13 için sirasılyla $22,0,5,0$ ve 2,0 sıklığında görülür ${ }^{1}$.

Fetal ultrason (US) prenatal girişimsel olmayan tanı yöntemleri içinde fetal risk ve annenin rahatlığı açısından en uygun olarak kullanılan yöntemdir. Bilgisayarlı tomografi ve magnetik rezonans görüntülenmesi hem pahalı hem de fetüsün radyasyondan etkilenmesi endișesiyle kullanımı sınırlıdır.

Maternal kandaki hücre dışı deoksiribonükleik asit (cell-free DNA, cfDNA) oranı 11-13 gebelik haftalarında yaklaşık \%10 iken, ilerleyen gebelik haftası ile artmakta ve genel olarak \%320 arasında değişmektedir. Doğum sonrası maternal kandaki düzeyi hızla azalmakta ve postpartum iki saat sonra ise tespit edilememektedir². Başlangıçta maternal kanda prenatal tanı sözcüğü kullanıldı ise de testin pozitifliği durumunda Amniyosentez (AS) ve koryonik villüs örneklemesi (CVS) gibi yöntemlerle elde edilen fetal hücrelerde geleneksel kromozom analiz tekniklerinin uygulanması gerektiğinden ve henüz $\% 100$ duyarllık ve özgüllüğe sahip olmadığından, yöntem ileri tarama testi olarak kabul edilmektedir ve genel olarak non-invaziv prenatal test (NIPT) olarak adlandırılmaktadır. Maternal kan, tanı çalışmalarından ziyade tarama çalışmalarında daha önemlidir.

Günümüzde fetal kromozomal ve genetik bozuklukların tanısında yaygın olarak AS kullanılmaktadır. Genetik bozuklukların tanısında midtrimester AS 15 ila 18. gebelik haftalarında yapılmaktadır. $\mathrm{Bu}$ haftalarda amniyon sıvı miktarı, viabl-non viabl hücre 
oranı prosedür için uygundur. İşlem öncesinde US ile fetüs sayısı, gestasyonel hafta, plasenta ve kord insersiyon yerleri tespit edilmeli, fetal viabilite belirlenmelidir. Amniyon sivisındaki fetal hücreler fetal deri, respiratuar traktüs, gastrointestinal traktüs, üriner traktüs ve plasentadan köken alır ve kültürlerde başarısızlık \%0,5'tir ${ }^{2}$. AS sonrasında 48 saat içinde gerileyen kramplar ve kasık ağrısı olabilir. Koryomniyonit \%0,3 oranında görülebilir ${ }^{3} \cdot \mathrm{Rh}$ uygunsuzluğu olan hastalara anti-D önerilmektedir.

AS endikasyonları başlıca ileri maternalpaternal yaş, habituel abortus, kromozomal anomalili bebek öyküsü, CVS mozaisizm saptanması, birden fazla serum belirteci kullanımında risk yüksekliği, nöral tüp defektli (NTD) bebek öyküsü, anormal US bulgusu, maternal anksiyete ve fetal durum tayinidir ${ }^{4}$.

AS işleminin fetal kayıp riski genelde $\% 1$ olarak verilmekle beraber deneyimli merkezlerde bu risk \%0,3'lere kadar inmektedir ${ }^{5}$.Uterusu çepeçevre kuşatan barsak gibi, işlemin teknik yönünü ilgilendiren durumlar hariç tutulursa, AS'in mutlak kontrendike olduğu bir hadise yoktur. Bununla birlikte insan immün yetmezlik virüsü (HIV) gibi maternal enfeksiyonlar veya diğer kan yoluyla geçen (örneğin Hepatit B gibi) enfeksiyonlar rölatif kontrendikedir. Çoğu otör işlemden önce HIV ile enfekte gebelerde ek bir Zidovudin dozu ile AS'i önermektedir6.

\section{YÖNTEMLER}

Çalışmamız için Dicle Üniversitesi Tıp Fakültesi Girişimsel Olmayan Klinik Araştırmalar Etik Kurulu'nda 22.01.2014 tarihli ve 190 numaralı onam alınd.

Çalışmamıza, Eylül 2011 ile Temmuz 2013 tarihleri arasında kliniğimizde AS uygulanan 217 olgu dâhil edildi. AS yapılmadan önce ayrıntılı US muayenesi yapıldı. Aileye AS'in yararı ve riskleri anlatıldı. Olgulara girișime bağlı muhtemel fetal kayıp ve diğer komplikasyonlar ile ilgili bilgi verildi. Riskleri kabul eden hastalardan ișlem öncesi onam alındı. AS uygulanan gebelerin yaşı, gravidası, paritesi, abortus sayısı, yaşayan çocuk sayısı, gebelik haftasl, varsa birinci ve ikinci trimester tarama testleri, US'de saptanan anomaliler ve plasentanın yerleşim yeri kaydedildi. Olgularda AS endikasyonları ise tarama testi pozitifliği, ileri anne yaşı, maternal anksiyete, daha önceden kromozom anomalili bebek doğurma hikâyesi, US'de fetal anomali düşündüren bulgular olarak belirlendi.

Bütün AS girişimleri tek kişi tarafından yapıldı. AS işlemine başlamadan önce batın antiseptik povidone iodine ile temizlendi. Daha sonra bir adet 2,5 ml'lik ve bir adet pistonu lastik olmayan 20 ml'lik iki steril disposible enjektör steril örtü üzerinde hazırlandı. Girişimler GE Voluson E8 Expert US cihazı eşliğinde, konveks probuna steril jelatin geçirilerek gerçekleştirildi. İşlem 13-23 gebelik haftaları arasında transabdominal olarak uygun amniyotik lokalizasyon belirlendikten sonra uygulandi. Tüm olgulara mümkün olduğu kadar transfundal veya üst uterin segmentlerden girilmeye çalışıldı. Yine tüm olgularda transamniyotik girildi, transplasental yol mümkün olduğunca tercih edilmedi. Tüm AS 22 gauge $120 \mathrm{~mm}$ 'lik disposible steril spinal iğneler ile yapıldı. Steril 2,5 ml'lik enjektörle alınan ilk 0,5-1,0 ml'lik sıvı alındıktan sonra 20 ml'lik steril enjektör ile her gebelik haftası için $1 \mathrm{ml}$ olacak şekilde amniyotik sıvı alındı. Gebelik haftası 20 haftanın üzerindeki gebelikler için de $20 \mathrm{ml}$ sıvı alındı. Alınan sıvı enjektör içinde ışıktan korunacak şekilde sarılıp sitogenetik analiz için uçak kargo ile genetik laboratuvarına (Intergen) gönderildi. 21 hafta ve üzerindeki olgularda, aile onamı da alınarak polimeraz zincir reaksiyonu (Polymerase chain reaction, PCR) veya floresan in situ hibridizasyon (FISH) yöntemiyle karyotipleme yapıldı.

Rh uyuşmazlığı olan gebelere immunizasyon riskine karşı işlemden hemen sonra 300 mikrogram anti-D immünglobülin uygulandı. 
Tüm hastalar doğumu gerçekleștikten sonra telefonla aranarak perinatal sonuçlar öğrenildi ve dosyalarına kayıt edildi.

\section{BULGULAR}

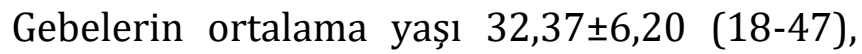
gebelik sayısı 2,59 $\pm 1,91(0-11)$, doğum sayısı $1,14 \pm 1,41$ (0-8), abortus sayısı 0,51 $\pm 0,91(0-5)$, çocuk sayısı 1,09 $\pm 1,03(0-8)$ olarak bulundu. Girişim yapılan gebelerin ortalama gebelik haftası 17,58 $\pm 1,80$ (13-23) olarak bulundu. Gebelerden AS ile ortalama 17,9 1 1,86 (13-20) $\mathrm{ml}$ amniyotik sıvı alındı. 3 olgu diamniyotik ikiz olmaları nedeniyle her birine ayrı girişim uygulandığı için iki kez iğne girişi yapıldı, diğer tüm olgulara tek iğne girişi uygulandı. Başarısız AS girișimi veya tekrar iğne girișimi olmadı. AS sırasında 203 hastada amniyotik sıvı berrak, 14 olguda bulanık olarak değerlendirildi.

AS endikasyonları incelendiğinde; ilk sırayı $\% 24,9$ ile pozitif üçlü test alırken, ikinci sırayı $\% 22$ ile birden fazla endikasyonu olan olgular, üçüncü sırayı \%21,7 ile pozitif US bulguları almaktadır (Tablo I).

Tablo I: Olguların AS endikasyonlarına göre dağılımı.

\begin{tabular}{|c|c|c|c|c|}
\hline \multirow[b]{2}{*}{ Endikasyon } & \multicolumn{2}{|c|}{ AS olguları } & \multicolumn{2}{|c|}{$\begin{array}{l}\text { Kromozomal } \\
\text { anomalili }\end{array}$} \\
\hline & $\mathrm{N}: 217$ & $(\%)$ & Sayısı & $\begin{array}{l}\text { Yüzde } \\
(\%)\end{array}$ \\
\hline Üçlü test & 54 & 24,9 & 4 & 7,4 \\
\hline Pozitif US bulguları & 47 & 21,7 & 8 & 17 \\
\hline İleri anne yaşı & 22 & 10,1 & 0 & 0 \\
\hline Aile isteği & 14 & 6,5 & 0 & 0 \\
\hline Kombine test & 19 & 8,8 & 0 & 0 \\
\hline Pozitif anamnez bulgusu & 7 & 3,2 & 0 & 0 \\
\hline Dörtlü test & 4 & 1,8 & 0 & 0 \\
\hline Toxo IgM (+) & 2 & 0,9 & 0 & 0 \\
\hline Birden fazla endikasyon & 48 & 22,1 & 6 & 12,5 \\
\hline
\end{tabular}

AS yapılan hastaların 18 inde (\%8) karyotip anormal saptandı. Bunlardan 6 olguda yaşamla bağdaşabilen karyotip anomalileri idi. Yaşamla bağdaşan ve bağdaşmayan anomaliler sırasıyla Tablo II, Tablo III ve Tablo IV'te verilmiștir.
Tablo II: Yaşamla bağdaşan anomaliler

\begin{tabular}{|c|c|c|c|c|c|}
\hline $\begin{array}{l}1 \\
8\end{array}$ & $\begin{array}{l}\text { An } \\
\text { ne } \\
\text { yaş } \\
1\end{array}$ & Karyotip & $\begin{array}{l}\text { US } \\
\text { Bulgul } \\
\text { arı }\end{array}$ & $\begin{array}{l}\text { AS } \\
\text { Endikasyo } \\
\text { nları }\end{array}$ & $\begin{array}{l}\text { Progn } \\
\mathrm{oz}\end{array}$ \\
\hline 1 & 40 & 46,XX,İVV(9)(P11q13) & Yok & $\begin{array}{l}\text { Üçlü test } \\
1 / 202\end{array}$ & $\begin{array}{l}\text { Yaşıy } \\
\text { or }\end{array}$ \\
\hline 2 & 35 & 46,XX,inv(9)(p11q13) & Yok & 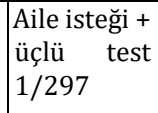 & $\begin{array}{l}\text { Yaşıy } \\
\text { or }\end{array}$ \\
\hline 3 & 38 & $46, \mathrm{XX}, \operatorname{der}(18)$ & KHF & $\begin{array}{ll}\text { Üंçlü } & \text { test } \\
1 / 25 & \end{array}$ & $\begin{array}{l}\text { Yaşıy } \\
\text { or }\end{array}$ \\
\hline 4 & 34 & $\begin{array}{ll}\text { nuc } & \text { ish } \\
(13 q 14, D 18 Z 1, D 21 S 259) * 2\end{array}$ & $\begin{array}{l}\text { Simetr } \\
\text { ik lugr }\end{array}$ & Us bulgusu & $\begin{array}{l}\text { Yaşıy } \\
\text { or }\end{array}$ \\
\hline 5 & 28 & $46, X X, I N N V, 13$ & KPC & Us bulgusu & $\begin{array}{l}\text { Yaşıy } \\
\text { or }\end{array}$ \\
\hline 6 & 31 & $\begin{array}{l}46, \mathrm{XX}(94) / 46, \mathrm{XX}, \mathrm{t}(8 ; 10)(\mathrm{q} 24.3, \\
\mathrm{q} 24.1)[4]\end{array}$ & Yok & $\begin{array}{lr}\text { Üçlü } & \text { test } \\
1 / 105 & \end{array}$ & $\begin{array}{l}\text { Yaşıy } \\
\text { or }\end{array}$ \\
\hline
\end{tabular}

US: Ultrasonografi KHF: Kardiyak hiper ekojen fokus CPC: Koroid pleksus kisti

Tablo III: Yaşamla bağdaşmayan veya sonlandırılan anomaliler

\begin{tabular}{|c|c|c|c|c|c|}
\hline $\begin{array}{l}\mathrm{N}: \\
18\end{array}$ & $\begin{array}{l}\text { An } \\
\text { ne } \\
\text { yaş } \\
\text { l }\end{array}$ & Karyotip & US Bulguları & $\begin{array}{l}\text { AS } \\
\text { Endikasyonlar } \\
\text { I }\end{array}$ & Prognoz \\
\hline 1 & 34 & Trizomi 13 & $\begin{array}{l}\text { Bil.Cerebral vent dilatasyon } \\
\text { Bil. yarık dudak damak } \\
\text { KHF, ASD, VSD, sep. } \\
\text { primum yok } \\
\text { Bil. böbrekler hiperdens ve } \\
\text { büyük } \\
\text { SUA } \\
\text { FL-AC geri }\end{array}$ & US bulgusu & $\begin{array}{l}\text { Preterm } \\
\text { doğum, } \\
\text { eks }\end{array}$ \\
\hline 2 & 24 & Turner & HEB & 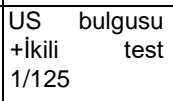 & $\begin{array}{l}\text { Ulaşılam } \\
\text { adı }\end{array}$ \\
\hline 3 & 27 & sendromu & $\begin{array}{l}\text { Kalın nt, nb izlenmedi , bil. } \\
\text { Nuchal kistik dilatasyon, dv } \\
\text { reverse a, genarelize ödem }\end{array}$ & US bulgusu & \begin{tabular}{|l} 
Tibbi \\
terminas \\
yon
\end{tabular} \\
\hline 4 & 38 & $\begin{array}{l}\text { Pallister- } \\
\text { Killian } \\
\text { sendromu } \\
(46 X Y(50) / \\
47 X Y+\dot{I}(12 \\
) \\
\left.(P 10)^{\wedge} 50\right)\end{array}$ & $\begin{array}{l}\text { Diafragma hernisi } \\
\text { Polihidramniyos } \\
\text { Ventrikülomegali } \\
\text { Serebral hipoplazi }\end{array}$ & US bulgusu & $\begin{array}{l}\text { Tıbbi } \\
\text { terminas } \\
\text { yon }\end{array}$ \\
\hline 5 & 36 & Trizomi 18 & $\begin{array}{l}\text { Bill. CPC } \\
\text { Omfalosel } \\
\text { Hipoplazik nazal bone } \\
\text { Mikrognati } \\
\text { Her iki el bileği flexiyonda } \\
\text { Cinsiyet net seçilemedi }\end{array}$ & US bulgusu & IUEF \\
\hline
\end{tabular}




\begin{tabular}{|c|c|c|c|c|c|}
\hline 6 & 38 & & $\begin{array}{lll}\text { Bil CPC, sol ayakta pes } & \text { pes } \\
\text { equinovarus, } & \text { SUA, } & \text { FL } \\
\text { kısalığı, VSD } & & \end{array}$ & US bulgusu & $\begin{array}{l}\text { Post } \\
\text { partum } \\
\text { ex }\end{array}$ \\
\hline 7 & 36 & $\begin{array}{l}\text { Triploi(69, } \\
\text { XXY) }\end{array}$ & $\begin{array}{l}\text { Simetrik IUGR } \\
\text { sağ böbrekte Pelvikalisyel } \\
\text { ektazi ASD-VSD }\end{array}$ & $\begin{array}{l}\text { US bulgusu + } \\
\text { Üçlü test } \\
1 / 187\end{array}$ & $\begin{array}{l}\text { Tibbi } \\
\text { terminas } \\
\text { yon }\end{array}$ \\
\hline 8 & 38 & Trizomi 10 & $\mathrm{KHF}$ & $\begin{array}{l}\text { Pozitif aile } \\
\text { anamnezi } \\
\text { [Önceki } \\
\text { gebelik ve } \\
\text { teyzede 46,xx } \\
\text { del(9,9q ter --) } \\
\text { 9q24:10q25-- } \\
\text { 10qter)del } \\
\text { (10)(pter-- } \\
\text { )q258parsiyel } \\
\text { triomi 10] } \\
+ \text { US bulgusu }\end{array}$ & $\begin{array}{l}\text { Tibbi } \\
\text { terminas } \\
\text { yon }\end{array}$ \\
\hline
\end{tabular}

US: Ultrasonografi, KHF: Kardiyak hiper ekojen fokus CPC: Koroid pleksus kisti ASD: Atrial septal defekt, VSD: Ventriküler septal defekt FL: Femur boyu AC: Abdominal çevre HEB: Hiper ekojen bağırsak SUA: tek umbilikal arter, IUEF: Intra uterin ex fetüs

Tablo IV: Down Sendromu saptanan anomaliler

\begin{tabular}{|c|c|c|c|c|c|}
\hline $\begin{array}{l}\mathrm{N}: \\
18\end{array}$ & \begin{tabular}{|l|} 
Anne \\
yaşı
\end{tabular} & Karyotip & US Bulguları & \begin{tabular}{|l|} 
AS \\
Endikasyonları
\end{tabular} & Prognoz \\
\hline 1 & 33 & $\begin{array}{l}\text { Down } \\
\text { send }\end{array}$ & $\begin{array}{l}\text { Simetrik IUGR } \\
\text { Hipoplazik NB } \\
\text { ASD, VSD, } \\
\text { Triküspit } \\
\text { stenozu, } \\
\text { Septum } \\
\text { primum } \\
\text { izlenmedi } \\
\text { Sandal gap }\end{array}$ & US bulgusu & $\begin{array}{l}\text { Tibbi } \\
\text { terminasyon }\end{array}$ \\
\hline 2 & 39 & $\begin{array}{l}\text { Down } \\
\text { send }\end{array}$ & $\begin{array}{l}\text { Extremite } \\
\text { kısalığ }\end{array}$ & $\begin{array}{l}\text { US bulgusu İkili } \\
\text { test } 1 / 8 \text {, Üçlü } \\
\text { test } 1 / 65\end{array}$ & $\begin{array}{l}\text { Tibbi } \\
\text { terminasyon }\end{array}$ \\
\hline 3 & 42 & $\begin{array}{l}\text { Down } \\
\text { send }\end{array}$ & \begin{tabular}{|l|} 
Kardiyak \\
hiperekojenik \\
fokus \\
Hiperekojenik \\
bowel \\
Hipoplazik \\
nazal bone \\
Duktus \\
venosusta \\
derin a
\end{tabular} & $\begin{array}{l}\text { US bulgusu+ } \\
\text { ileri yaş }\end{array}$ & $\begin{array}{l}\text { Tibbi } \\
\text { terminasyon }\end{array}$ \\
\hline 4 & 40 & $\begin{array}{l}\text { Down } \\
\text { send }\end{array}$ & $\begin{array}{l}\text { Kistik } \\
\text { higroma, } \\
\text { nuchal } 4 \text { adet } \\
\text { kist, kalın NT }\end{array}$ & US bulgusu & $\begin{array}{l}\text { Tibbi } \\
\text { terminasyon }\end{array}$ \\
\hline
\end{tabular}

US: Ultrasonografi, IUGR: intra uterin gelişme geriliği, ASD: Atrial septal defekt, VSD: Ventriküler septal defekt, NT: Nukkal kalınlık
AS yapılan hastalardan US'de fetal anomali saptanan ve bu nedenle AS uygulanan olgularda en slk kardiyovasküler anomali $25(\% 11,5)$ hastada izlendi.

AS uygulanan olguların hiç birinde girişimden sonra ilk üç haftada spontan abortus izlenmedi. AS uygulanan üç olguda miad doğumdan sonra kaybedildiği saptandı. Bunlardan ikisinde US'de fetal anomali saptanmış, diğerinde ise $A S^{\prime}$ de Trizomi 18 saptanmış ancak ailenin terminasyonu kabul etmediği belirlendi (Tablo V).

Tablo V: AS uygulanan olguların gebelik seyri

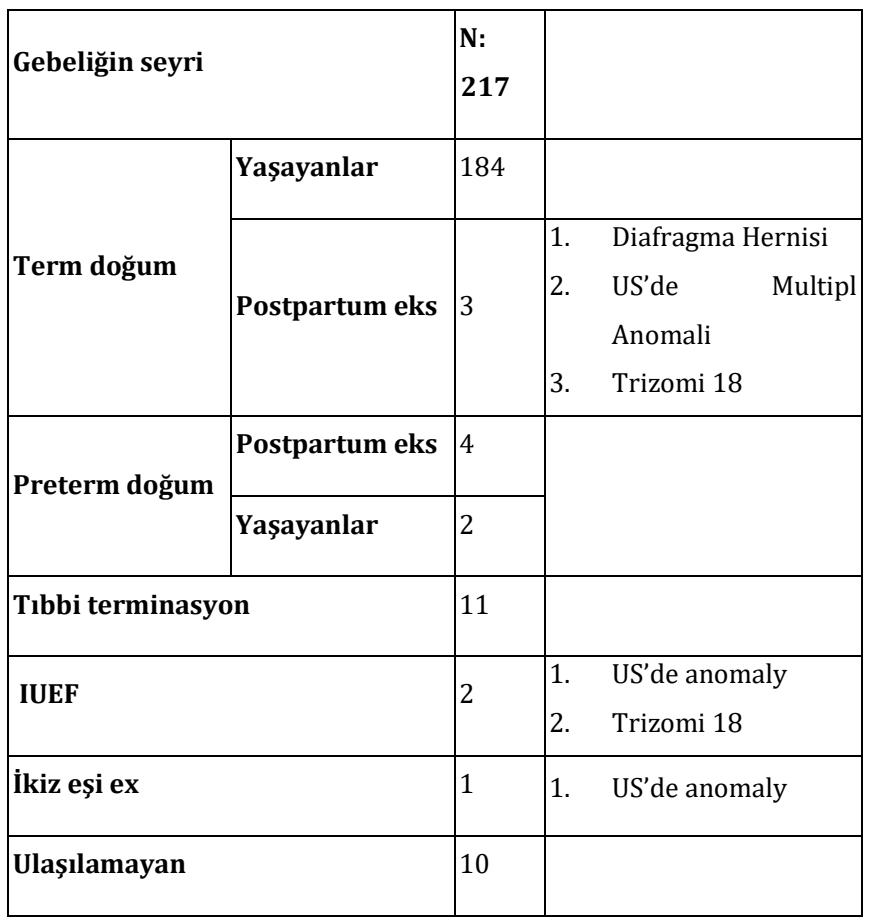

US: Ultrasonografi, , IUEF: Intra uterin ex fetüs

\section{TARTIŞMA}

Günümüzde AS prenatal invaziv girişimlerin en sık uygulananıdır ve genetik amaçlı olarak en sık ileri anne yaşı ve tarama testlerinde artmış risk nedeniyle yapılmaktadır. Gebeliklerin yaklaşılk \%2-3'ünde uygulanan bu işlem en sık 16-18. gebelik haftasinda yapılır7. Milewczyk ve ark retrospektif 420 AS olgu çalışmalarında ortalama yaş 37,6 olarak bulmuşlardır ${ }^{7}$. Çalışmamızda yaş grupları beșer yaş aralığı 
alınarak gruplara ayrıldı. En sik grup aralığı olarak 30-34 yaş grubu saptandı. Gebelerin yaş ortalaması 31,2 olarak bulundu. Milewczyk ve ark serilerindeki yaş ortalamasının bizim hastalarımızınkinden yüksek olmasının sebebi, bizim 35 yaş üstündeki tüm hastalara AS yapmamamızdan kaynaklandığını düşünüyoruz. Ancak ailenin AS istemesi durumunda, biyokimyasal test sonuçları ve US bulguları da göz önüne alınarak yüksek riskli hastalara direkt AS uyguladığımız olgularımız da vardır. Düşük risk saptanan hastalara AS önerilmedi, ancak nadiren çok düşük risk olmasına rağmen ailenin talebi üzerine de AS uygulanmıştır.

AS endikasyonları incelendiğinde; Acar ve ark \%518 Milewczyk ve ark \%877 ile en sı ileri anne yaşı endikasyonlarını bulmuşlardır. Çalışmamızda AS endikasyonlarını incelediğimizde ise maternal biyokimyasal testlerden üçlü testte yüksek risk olması en sık $(\% 30,87)$ endikasyonu oluşturmaktadır. Bulduğumuz bu oran Coşkan ve ark. yaptığı çalışma ile benzer özelliktedir9. Maternal yaş ise $\% 17,05$ ile dördüncü sırada yer almaktadır. Bunun nedeninin yukarıda anlatıldığı gibi çalışmamızda AS için kesin bir yaş sınırı koymamamı olduğunu düşünmekteyiz. Çalışmamızda ikinci sıklığı pozitif US bulguları oluşturmaktadır $\quad(\% 29,49)$. Çalışmamızda; birden fazla (kombine endikasyonlar) parametrenin oluşturduğu endikasyon üçüncü sırada $(\% 22)$ ve ileri anne yaşı ise dördüncü sırada $(\% 17,05)$ yer almaktadır.

AS uygulanan olgularda kromozomal anomali oranı çeşitli çalışmalarda \%2,5 ile \%4,5 arasında tespit edilmiştir. Acar ve arkadaşları serilerinde kromozom anomali oranını \%3,6 olarak bulmuşlardır ${ }^{8}$ AS uygulanan olgularımızdan toplam 18 olguda (\%8) kromozomopati saptanmıştır. Bunlardan 6 olguda yaşamla bağdaşır kromozomal anomali saptanmıștır. Bunları çıkardığımızda ise 12 olguda $(\% 5,5)$ gerçek kromozomal anomali saptandığı ortaya çıkmaktadır. Kromozomal anomali saptanan olgularımızdan 4 Trizomi 21 (Down sendromu), 2 Trizomi 18 (Edward sendromu), 2 Turner sendromu ve sirasiyla birer olguda Trizomi 13 (Patau sendromu), Trizomi 10, Triploidi ve bir olguda da Parsiyel Tirizomi 10 (Pallister-Killian sendromu) izlendi. En sık saptadığımız kromozomal anomalisi olan Down sendromu, literatürdeki diğer çalışmalarla benzerdir ${ }^{10}$. Kromozomal anomali oranına baktığımızda oranımızın literatürden daha yüksek olduğu görülmektedir. Bu da AS endikasyonunda çok daha seçici davrandığımızı göstermektedir.

Acar ve ark serilerinde üçlü testte artmış risk nedeni ile AS yaptıkları olgularda kromozom anomali oranını \%0,9 olarak bulmuşlardır8. Üçlü testte yüksek risk nedeni ile AS uyguladığımız 54 olgudan $6(\% 7,4)$ olguda kromozom anomalisi saptand.

Ultrasonda fetal anomali tespiti nedeni ile yapılan AS serilerinde kromozom anomalisi tespit edilme oranları arasında belirgin farklar vardır. Bu oran çeşitli serilerde \%4 ile \%27,1 arasında bildirilmektedir. Stoll ve arkadaşları, fetal US'de anomalisi olan 119 olguda yaptıkları AS sonrası \%8,9 oranında kromozom anomalisi belirlemişlerdir ${ }^{11}$. Rizzo ve arkadaşları, US'de fetal anomali saptadıkları 173 fetusta \%16,8 oraninda kromozom anomalisi belirlemişlerdir ${ }^{12}$. Hsieh ve arkadaşları fetal US anomalisi olan 148 olguda \%20,27 oranında kromozomal anomali göstermişlerdir ${ }^{13}$. US'de fetal anomali tespiti nedeni ile 47 olguda yaptığımız AS'de 8 (\%17) olguda kromozom anomalisi tespit edildi ve bu bulgumuz Çetin ve ark. yaptıkları çalışma ile örtüşmektedir $(\% 7,1)^{14}$. Bu veriler gösteriyor ki $A S^{\prime} d e$ kromozom anomalisi yakalayabilme olasılığı maternal yaş ve üçlü testten ziyade en sık US'de fetal anomali saptanan olgularda görülmektedir. Birden fazla endikasyon nedeniyle AS uyguladığımız 48 hastadan 6 olguda $(\% 12,5)$ kromozomopati bulundu. Bu da 
bize birden fazla neden ile yapılacak AS olgularında kromozomal anomali yakalama oranının daha yüksek olabileceğini göstermektedir.

Acar ve ark çalışmalarında ileri yaş nedeniyle yapılan AS'de kromozomal anomali oranını \%1 olarak bildirmişlerdir8. İzole ileri anne yaşı nedeni ile AS uyguladığımız 22 olgunun hiçbirinde kromozomal anomali saptanmadı. Biz yaşın diğer parametrelerle kombine edilmesi gerektiği, aksi takdirde izole yaştan dolayı gereksiz AS sayısının artacağını düşünmekteyiz.

Anomalili çocuk öyküsü olan ya da yakın aile bireylerinde anomali olan çiftlerin gebelikleri sırasında artmış anomali riski vardır. Önceki gebeliğinde Down sendromlu çocuk doğuran gebelerin sonraki gebeliklerinde Down sendromlu bebek doğurma riski yaklaşık olarak $\% 0,75^{\prime}$ tir $^{15}$. Bizim çalışmamızda pozitif aile anamnezi olarak gruplandırdığımız bu grupta 9 hastamız mevcuttu ve bunlardan 1 tanesinde (\%11) Trizomi 10 saptanmıștır.

Acar ve ark yaptığı çalışmada gebelik kaybı oranı \%0,42 (16/3721) olarak izlenmiştir8. Eddlemann ve ark 1605 olguluk serilerinde fetal kayıp oranını \%0,15 olarak bulmuşlardır ${ }^{16}$. Anderson ve arkadaşları, 1200 olguluk AS serilerinde $\% 0,80$ fetal kayıp bulmuşlardır ${ }^{17}$. Eydoux, yaptığı çalışmada \%1,3 oranında fetal kayba rastlamıștır ${ }^{18}$.

Çalışmamızda AS yapılan 217 olgudan hiçbiri AS sonrası ilk bir ay içinde gebeliğini kaybetmemiştir.

$\mathrm{Bu}$ çalışmamızda ilk trimester kombine tarama testinin olmaması ve değerlendirilememesi araștırmamızın sınırlılıklarındandır. Yassaee ve ark. yaptığ çalışmada ilk trimester tarama testine göre AS yapılan olguların \%17,1'inde kromozomal anomali saptamışlardır ${ }^{19}$. Biz ilk trimester kombine test pozitif saptadığımız zaman CVS öneriyoruz. AS için beklemiyoruz.

\section{SONUÇ}

Yaptığımız çalışmada kromozomal anomaliler daha çok US' de fetal anomali saptanan ve birden çok nedene bağlı endikasyonlar ile AS uygulanan hasta gurubunda saptanmıștır. Bu da prenatal tanı amacıyla yapılan anomali taramasının deneyimli ve konunun uzmanları tarafından yapılmasının daha yararlı olacağını göstermektedir. Yine birden çok pozitif parametre (kombine endikasyon) saptanan olgulara da AS uygulanması durumunda kromozomal anomali yakalama şansı daha yüksektir. Merkezimiz tersiyer bir merkez ve perinatoloji birimi olduğu için referans merkezi konumundadır. Bundan dolayı riskli ve majör anomalili grup ile çalıştığımız için perinatal kayıp riski işlemden bağımsız olarak yüksek çıkabilmektedir. Yalnız ileri anne yaşının kromozomal anomali yakalama şansını fazla artırmadığını düşünüyoruz.

Etik Kurul Kararı: Çalışmamız için Dicle Üniversitesi Tıp Fakültesi Girişimsel Olmayan Klinik Araştırmalar Etik Kurulu'nda 22.01.2014 tarihli ve 190 numaralı onam alındı.

Çıkar Çatışması Beyanı: Yazarlar çıkar çatışması olmadığını bildirmişlerdir.

Finansal Destek: Bu çalışma her hangi bir fon tarafından desteklenmemiştir.

Declaration of Conflicting Interests: The authors declare that they have no conflict of interest.

Financial Disclosure: No financial support was received.

\section{KAYNAKLAR}

1. Loane M, Morris JK, Addor MC, et al. Twentyyear trends in the prevalence of Down syndrome and other trisomies in Europe: impact of maternal age and prenatal screening. Eur J Hum Genet. 2013; 21: 27-33.

2. Invernizzi $\mathrm{P}$, Biondi $\mathrm{M}$, Battezzati $\mathrm{P}$ et al. Presence of fetal DNA in maternal plasma decades after pregnancy. Human genetics. 2002 Jun 1; 110: 587-91. 
3. Cederholm M, Haglund B, Axelsson 0 . Maternal complications following amniocentesis and chorionic villus sampling for prenatal karyotyping. BJOG: An International Journal of Obstetrics \& Gynaecology. 2003 Apr; 110: 392-9.

4. American College of Obstetricians and Gynecologists. Practice Bulletin No. 162: Prenatal Diagnostic Testing for Genetic Disorders. Obstetrics and gynecology. 2016 May; 127: e108.

5. Alfirevic Z, Navaratnam $\mathrm{K}$, Mujezinovic $\mathrm{F}$. Amniocentesis and chorionic villus sampling for prenatal diagnosis. Cochrane Database Syst Rev. 2017; 9: CD003252. Published 2017 Sep 4.

6. Andany N, Letchumanan M, Bondy L, Murphy K, Loutfy MR. Amniocentesis in the HIV-infected pregnant woman: Is there still cause for concern in the era of combination antiretroviral therapy?. Can J Infect Dis Med Microbiol. 2013; 24: e91-e95.

7. Milewczyk P, Lipiński T, Hamela-Olkowska A, et al. Ocena wyników amniopunkcji genetycznych w materiale II Kliniki Połoznictwa i Ginekologii AM w Warszawie [Genetic amniocentesis in the II Department of Obstetrics and Gynecology of the Medical University of Warsaw]. Ginekol Pol. 2004 Aug; 75: 603-8. Polish. PMID: 15517783.

8. Acar A, Ercan F, Yildirim S, et al. Genetik Amniyosentez Sonuçlarimiz: 3721 Vakanin Analizi. Şişli Etfal Hastanesi Tip Bülteni. 2016; 50: 33 .

9. Çoşkan A, Sel G, Harma M. Amniyosentez İşlemi, Uterin ve Umbilikal Arter Doppler Ölçümlerinde değişiklik yaratır mı?. Harran Üniversitesi Tıp Fakültesi Dergisi, 2019;16: 105-10.

10. Saatçi Ç, Bayramov R, Başbuğ $M$, et al. Retrospective evaluation of results of 3617 invasive prenatal diagnosis cases applied between 1997-2015 years. Sağlık Bilimleri Dergisi. 2016; 25: 120-5.

11. Stoll C, Dott B, Alembik Y, et al. Evalution of routine prenatal ultrasound examination in detecting fetal chromosomal abnormalities in a low risk population. Hum Genet 1993; 91 : 37 41.

12. Rizzo N, Pittalis MC, Pilu G et al. Prenatal karyotyping in malformed fetus. Prenat Diagn 1990; 10: $17-23$.

13. Hsieh FJ, Ko TM, Tseng LH, et al. Prenatal cytogenetic diagnosis in amniocentesis. J Formos Med Assoc, 1992;91: 276-82.

14. Çetin 0, Verit Atmaca F, Zebitay A, et al. Second Trimester Genetic Amniocentesis: FiveYear Experience of a Maternal- Fetal Medicine Unit. Gynecology Obstetrics \& Reproductive Medicine, 2016; 19: 147-52.

15. Wapner RJ, Lorraine D. Creasy and Resnik's Maternal-Fetal Medicine: Principles and Practice, Eighth Edition Philadelphia :Elsevier ,2019: 493-538.

16. Eddleman K, Berkowitz R, Kharbutli Y, et al. Pregnancy loss rates after midtrimester amniocentesis: The FASTER trial. Am J Obstet Gynecol 2003; 189: S111.

17. Anderson RL, Goldberg JD, Golbus MS. Prenatal diagnosis multipl gestation. 20 years experience with amniocentesis. Prenatal Diagnosis, 1991; 11: 263-70.

18. Eydoux P, Choiset A, Porrier NL, et al. Chromosomal prenatal diagnosis: Study of 936 cases of intrauterin abnormalities after ultrasound assessment. Prenat Diagn, 1989; 9: 255-68.

19. Yassaee F, Shekarriz-Foumani R, Sadeghi S. Amniocentesis Following Positive First Trimester Combined Screening: A Comparative Study. Acta Med Iran. 57: 359-62. 